\title{
Research on Computer Major”3+2”Staging and Connecting Training Mode Innovation Under Life-long Education Background
}

\author{
Aizhang Guo ${ }^{1, \mathrm{a}, *}$, Xiufang $\mathrm{Li}^{1, \mathrm{~b}}$ \\ ${ }^{1}$ College of Information, Qilu University of Technology(Shandong Academy of Sciences) \\ Daxue Road, Changqing District, Ji'nan, China \\ a gaz@qlu.edu.cn, bcarol_xiufang@163.com \\ *corresponding author
}

Keywords: Vocational Education, Life-long Education, ”3+2”Staging and Connecting Training, Talent Training Mode

\begin{abstract}
Building modern vocational education system is a basic channel to push forward lifelong study society formation and sustainable development. " $3+2$ "staging and connecting training between higher vocational college and undergraduate college is an important component of modern vocational education system. Computer major is an emerging major used widely. Directing at the problems existing in the present" $3+2$ "staging and connecting training and combining life-long education background, this text carries out innovation research on the existing connecting mechanism and talent training mode and forges a new "overpass" for vocational education, so as to not only complete modern vocational education system frame but also help cultivate versatile talents for the society.
\end{abstract}

\section{Background of Life-long Education}

The construction of modern vocational education system is a systematic project. The eighteen major reports of the party put forward: The construction of a learning society is an important part of the social and cultural construction. In our country, the fundamental motive force of building a well-off society is to meet the basic learning needs of all the people and promote the whole people's learning and lifelong learning. In the environment of life-long education, the ultimate goal of education is to pursue sustainable development and promote the construction of a harmonious society. As a part of life-long education, the improvement of vocational education can lay a good foundation for lifelong education. To speed up the development of vocational education and build a modern vocational education system is the basic way to promote the formation of lifelong learning society. Higher vocational education from single to multiple, from closed to open, from the end of academic credentials to continuous upgrading is the basic trend and basic trend of the development of higher vocational education in the world. It is the general trend to build the concept of vocational education development with the perspective of lifelong education. The training mode between higher vocational and undergraduate colleges is the key to the realization of lifelong education from vocational education.

\section{Problems Existing in"3+2"Mode}

Staging and connecting training between higher vocational college and undergraduate college (hereafter referred to as " $3+2$ ") means students studying for three years at higher vocational college and then studying for two years at undergraduate college after they pass the qualification examination. During students studying, the two colleges cooperate with each other and complement each other to make the five-year connecting training form a complete education system and systemically cultivate application technology-type professional talents with undergraduate level.

Because Chinese vocational education starts relatively late, currently the following problems exist:talent training objective of trial major is indefinite;course system construction is unreasonable; 
only repetition is avoided in major core course linking and no integrated and unified design is formed; course content and teaching method are still difficult to get rid of disciplinary system type and highlight "competency-based" idea; course implementation and assessment methods always follow the practice of higher vocational college without innovation; teaching material construction lags behind; teachers have no clear idea and keep using previous teaching mode and invariable teaching method; practice teaching conditions don't meet the requirements of staging and connecting training; fixed school system isn't in line with the trend of credit system reform; mutual recognition of credits of higher vocational college and undergraduate college is insufficient and teaching resources such as network study platform haven't been made full use of ; the participation of enterprises in talent training scheme formulation, course development and talent training process need be further deepened; intercollege resource (faculty, place, equipment, practical training base) sharing need be further strengthened; teaching staff team construction can't meet the requirements of pilot project.

\section{3. “3+2” Staging and Connecting Training Mode Innovation Under Life-long Education Background}

\subsection{Formulate Integrated Linking Training Objective Relying on Application and Skill}

Computer major is an emerging major used widely, mainly including Internet of Things Engineering, computer science and technology, software engineering, network engineering and digital media technology. Because such major stresses application and skill, which results in great demand on talents, it is of huge influence on national economy and social development. Therefore, we should take cultivating skill-type, application-type and innovation-type versatile talents as ultimate objective.

Based on the actuality of colleges in Shandong province, the ultimate objective of “3+2" computer major talent training is: "advanced application-type talents mastering basic theory and specialized knowledge of computer application, having innovation consciousness and strong operational capability and being able to carry out computer system management maintenance and application technology service in the forefront of production using computer application technology". Under this ultimate objective, we carry out integrated linking of the objective of higher vocational college and that of undergraduate college. The training objective of higher vocational education is training students to make them have professional skill, i.e. making students become operation-type, skill-type and utility-type talents, while that of undergraduate education is making students become management-type, application-type and advanced technology-type talents. Complementing each other, the two face modern technology application and management posts and highlight vocational competence training.

\subsection{Carry out Reasonable Overall Planning to Realize Seamless Linking of Course System}

With courses being important carrier of talent training scheme, linking of various courses is a core problem in connecting of higher vocational education and undergraduate education.

\subsubsection{Carry out Mutual Consultation and Tiered Boosting to Ensure Scientificity and Completeness}

In course linking, cooperative institutions need do research and consultation to carry out overall design and reasonable planning of course teaching. We should avoid the repetition and disjunction of teaching contents of higher vocational education and undergraduate education and make them form gradients to realize the continuity, succession and integration of course setting and help students increase their knowledge, quality and capability progressively. We should set a great number of professional electives, specialty-oriented courses and practical activities to put quality education and innovation \& entrepreneurship education throughout course system and realize student individuality cultivation. 


\subsubsection{Avoid Repetition, Attach Importance to Knowledge Linking and Highlight Staging Training Objective}

We should focus on training of students' professional basic skill and occupational quality on the basis of strengthening professional theory and knowledge learning in the first three years and pay attention to training of students' professional core capability and comprehensive capability while strengthening professional theory and knowledge learning in the second two years. Higher vocational education should enlarge proportion of professional basic course and cultural basic course to prevent students from having difficulty in learning professional theory after entering into undergraduate college.

\subsubsection{Attach Importance to Industry Development, Carry out Systematic Management on Courses and Update Knowledge System Timely}

With computer science and technology being upgraded very quickly, in order to make students able to contact the most cutting-edge computer professional knowledge and technology during the overall learning process, we must add new knowledge and subject contents to course contents and keep course contents of higher vocational college and undergraduate college consistent.

\subsection{Introduce Enterprise Participation and Realize Synchronization of College-enterprise Cooperation with " $3+2$ " Staging}

Currently, “3+2"training system only involves cooperation of higher vocational college and undergraduate college and lacks participation of enterprises. Because enterprises represent social demand and industry developing capability, training students by cooperating with enterprises not only improves students' practice capability and innovation capability but also helps students carry out reasonable occupational planning to improve social productivity and promote social development. Therefore, in "3+2"training mode, partners should include three parties of undergraduate college, higher vocational college and enterprise, so as to form " $3+2+1$ " mode and give full play to third-party function of enterprises. We should choose enterprises with sufficient qualification based on major features, formulate different college-enterprise cooperation schemes at different stages, and realize synchronization of college-enterprise cooperation with " $3+2$ " staging in course setting, course resource, teacher cultivation and practice base construction. Criteria measuring qualification of cooperative enterprises include completeness of software and hardware platforms such as course system, college teacher training capability, remote resource sharing, teaching management, and instructional interaction. On the basis of fulfilling the above cooperative elements, both college and enterprise carry out college-enterprise cooperation oriented by enterprise demand and the cooperative enterprise participates in the whole teaching process during students studying at college so as to timely adjust professional core course in course setting based on IT industry development. They also can establish a advanced enterprise software practical training center jointly; the cooperative college provides place to establish an enterprise software technology practical training center.

\subsection{Implement Flexible Education System and Flexible Credit System Reform and Realize Student Individuality Development}

With social development, students face more choices such as startup, taking postgraduate entrance exam, earlier employment and so on, and “ $3+2$ "should respect student individuality development and social needs to implement flexible education system and flexible credit system reform.

Perfect flexible education system: new students can apply for retention of admission qualification to carry out innovation and startup practice; they also can apply for suspension of schooling to carry out startup after admission; for the students applying for suspension of schooling to carry out startup, the college should specify the longest schooling period and simplify approval procedures for suspension of schooling. Students at higher vocational college can enter into undergraduate college for studying in advance if they fulfill credit of the corresponding stage within 
two years. Students at undergraduate college can graduate in advance by fulfilling credit in advance. Such measure can make students finish schooling actively and efficiently and help realize training objective quickly.

Perfect flexible credit system: establish “3+2”five-year overall credit system to make students able to choose specialty direction and corresponding courses more freely so as to improve their learning efficiency and avoid education resource wasting. The participation of students in open-type network course study, innovation \& startup activities and skill competition accepted by the college can be converted into credit and included in overall credit. The training certificate and national occupational qualification certificate students obtain in the stage of higher vocational college are allowed to be converted into credit of the stage of higher vocational college or undergraduate college, so as to avoid students' repetitive study.

\subsection{Push forward Resource Sharing within Colleges in Shandong Province and Explore Teacher Sharing Resource Mode}

Quality teaching resource is one of core elements of " $3+2$ " system. We should build MOOC platform conforming to computer major and launch large-scale teaching resource construction activity to realize the fullest sharing of resource and teacher strength, with the help of existing internet resource, led by the government competent department, and based on professional teaching standards.

Unite colleges within the province to purchase or establish a large batch of quality resource sharing courses, and carry out construction of resources such as teaching materials, excellent network courses, network platform and multimedia courseware using the latest education technology, so as to satisfy teaching resource demand under " $3+2$ " mode.

Realize three-party education teaching resource sharing of higher vocational college, undergraduate college and cooperative enterprise, including school-outside practical training base sharing, laboratory practical training center sharing, book resource sharing, project resource sharing, information resource sharing and so on. Give full play to their respective advantages, for example, the undergraduate college provides richer academic resource, talent resource and technology resource; the higher vocational college provides richer experience of college-enterprise cooperation, stronger teacher practice capability and more complete practical training teaching conditions; the enterprise provides project resource, practical training resource and part-time teacher resource.

\subsection{Implement “Connecting Tutor" System and Enhance "Double Type” Teaching Team Construction}

Unite the enterprise to enhance "double type" teacher cultivation and establish tutor survey, teaching quality monitoring and teaching feedback system. Improvement of teacher quality is the key of operation of higher vocational college-undergraduate college connecting mechanism. Colleges should enhance allocation of professional teacher team and set up " $3+2$ " course teaching team according to quality teaching resource allocation principle. The teaching team should reflect teacher strength structure with double subjects of college and enterprise; the theory courses should take college teachers as subject and the practice courses and links should take enterprise industry teachers as subject; frontline teachers of college and enterprise industry should be absorbed to become team members, so as to realize teacher connecting and powerful combination. Advise teachers to change teaching concept and reform teaching method and encourage them to carry out course design, classroom teaching and professional skill teaching practice.

Implement "connecting tutor" system. Because student management and student career planning are the key links of " $3+2$ " talent training, we should implement "connecting tutor" system based on students and help students acquire cognition and realize self-value in a targeted way. "Connecting tutor" means students fixing a teacher of undergraduate college as academic tutor in the five years of " $3+2$ " system; at the time of admission of higher vocational college, "connecting tutor" two-way selection is carried out, and after "connecting tutor" is determined, this teacher is responsible for the academic guidance of this student at both higher vocational college and undergraduate college. The student can carry out individual specialty interest choice and occupational planning to form 
individuality knowledge system, under the teacher's guidance; meanwhile the tutor can formulate reasonable academic tutoring planning directing at the student's situation so as to help the student build confidence and grow healthily.

\section{Conclusion}

" $3+2$ " staging and connecting training is an important component of modern vocational education system, and as an emerging major stressing application, computer major influences social and national economic development. This text researches how to take advantage of" $3+2$ " training to cultivate excellent computer professional talents under life-long education background. Directing at the problems existing in the present " $3+2$ " mode, this text carries out several kinds of innovation on " $3+2$ " training mode to complete modern vocational education system and cultivate high-level application technology-type professional talents for economic growth transformation, meanwhile, it offers thinking for undergraduate and graduate connecting education so as to help build a new overpass of vocational education.

\section{Acknowledgements}

The article is funded by the educational research project of Qilu University of Technology (NO.041201034116).

\section{References}

[1] Zhao Haoyu. (2013)Thinking on the training mode of "3+2" in Higher Vocational College and ordinary undergraduate course. Higher Vocational Research in Changzhou Institute of Engineering Technology, 1, 2-3.

[2] Wang Yaming, Wang Juan. (2014)Research on the Status,Predicament and Countermeasures of Higher Vocational Undergraduate Education in China. Chinese Higher Education Research, 3, 9194.

[3] Zhu Ping. (2014)Rethinking on the Connection between Higher Vocational and Applied Undergraduate Courses. Vocational Education Forum, 4, 65-67.

[4] Jiang Dayuan. (2014)Modern vocational Education and the Construction of National Qualification Framework. Vocational and Technical Education in China, 21, 102-103.

[5] Li Yu. (2012)Some Thoughts on the Training Mode of Middle and Higher Vocational Education. Vocational Education Forum, 22, 164-165. 